\title{
PENERAPAN METODE REGRESI RIDGE DALAM MENGATASI MULTIKOLINIERITAS PADA TINGKAT FERTILITAS WANITA USIA SUBUR
}

\author{
Rahmi Susanti ${ }^{1)}$, Canda Dwi Giyatri' ${ }^{2)}$, Ismail AB ${ }^{3)}$ \\ ${ }_{1,2,3}$ Fakultas Kesehatan Masyarakat, Universitas Mulawarman, Samarinda, Indonesia \\ email: rahmi.susanti@fkm.unmul.ac.id
}

\begin{abstract}
Abstrak
Multikolinieritas merupakan asumsi pada regresi linear berganda yang terjadi karena korelasi antar variabel bebas yang menyebabkan permasalahan analisis. Penanganan yang dilakukan salah satunya dengan regresi ridge, yang dapat memastikan varians yang lebih kecil dalam estimasi parameter. Multikolinieritas pada data fertilitas menyebabkan varian dan galat yang besar. Penelitian ini bertujuan mengetahui determinan yang mempengaruhi fertilitas, deteksi multikolinieritas dan membuat model prediksi terbaik pada fertilitas wanita usia subur di Kalimantan Timur. Penelitian ini menggunakan desain crosssectional dan metode analisis data regresi linier berganda dan metode ridge. Data yang digunakan merupakan Survei Demografi dan Kesehatan Indonesia (SDKI) tahun 2017 dengan dengan sampel sebanyak 701 WUS. Hasil penelitian diperoleh regresi ridge sebagai pemodelan terbaik dalam memprediksi tingkat fertilitas. Nilai VIF dan standar error yang lebih kecil dari MKT menjadikan regresi ridge sebagai pemodelan terbaik dalam menentukan tingkat fertilitas di Kalimantan Timur. Pemodelan regresi ridge yang digunakan dalam memprediksi tingkat fertilitas $Y^{R}=2,995148-0,01406898$ (umur seks pertama) 0,0119283 (umur kawin pertama) - 0,04233311 (umur pertama melahirkan) + 0,1001676 (lama kontrasepsi) $+0,1802514$ (jumlah anak ideal) + 0,1679205 (kematian anak) - 0,005938239 (Indeks kekayaan). Umur seks pertama, umur kawin pertama, umur pertama melahirkan, lama KB dan jumlah anak ideal berpengaruh signifikan dengan tingkat fertilitas. Perlu dilakukan peningkatan pengetahuan mengenai kesehatan reproduksi bagi WUS (15-49 tahun) guna menurunkan tingkat fertilitas dan laju pertumbuhan penduduk.
\end{abstract}

Kata kunci: fertilitas, wanita usia subur, regresi ridge

\begin{abstract}
Multicollinearity is an assumption in multiple linear regression that occurs because the correlation between independent variables causes analysis problems. One of the treatments is ridge regression, which can ensure a smaller variance in parameter estimation. Multicollinearity infertility data causes large variants and errors. This study aims to determine the determinants that affect fertility, detect multicollinearity and make the best prediction model for the fertility of women of childbearing age in East Kalimantan. This study used a cross-sectional design and data analysis method of multiple linear regression and ridge method. The data used is 2017 Indonesian Demographic and Health Survey (IDHS) with a sample of 701 WUS. The results obtained ridge regression as the best modeling in predicting fertility rates. The VIF value and standard error which is smaller than MKT make ridge regression the best model in determining the fertility rate in East Kalimantan. Ridge regression modeling used in predicting fertility rates $Y^{R}=2.995148-0.01406898$ (age at first sex)-0.0119283(age at first marriage)-0.04233311(age at first birth)+0.1001676(contraceptive time $)+0.1802514$ (ideal number of children) +0.1679205 (child mortality)-0.005938239(wealth index). Age at first sex, age at first marriage, age at first delivery, length of family planning, and the ideal number of children had a significant effect on fertility rates. It is necessary to increase knowledge about reproductive health for female women (15-49 years) in order to reduce the fertility rate and population growth rate.
\end{abstract}

Keywords: fertility, women of childbearing age, ridge regression

\section{PENDAHULUAN}

Multikolinieritas adalah salah satu asumsi yang mempengaruhi ke akuratan hasil analisis data pada analisis regresi linear berganda, selain beberapa asumsi lainnya yaitu data berdistribusi normal, outlier, autokorelasi, multikolinieritas, dan heterogenitas (Montgomery, Peck dan Geoffrey, 2012). Multikolinieritas dapat menghasilkan nilai koefisien regresi, interval dan standard error yang besar serta hubungan variabel yang tidak signifikan 
(Kurniawan dan Yuniarto, 2016). Apabila multikolinieritas diatasi dengan menghilangkan variabel maka akan menimbulkan bias spesifikasi model regresi karena variabel bebas yang dihapus berpeluang untuk mempengaruhi variabel dependen (Basuki, 2016). Sehingga, penggunaan regresi ridge lebih baik bila digunakan untuk menyelesaikan permasalahan asumsi multikolinieritas karena penduga koefisien yang dihasilkan cenderung lebih stabil dibandingkan metode kuadrat terkecil (Chatterjee dan Hadi, 2006).

Penggunaan regresi banyak digunakan di hampir setiap bidang, termasuk dalam bidang kesehatan masyarakat bidang kependudukan salah satunya tingkat fertilitas karena memungkinkan adanya identifikasi dan karakterisasi hubungan dengan banyak faktor (Schneider, Hommel dan Blettner, 2010). Indonesia merupakan negara dengan penyumbang angka fertilitas tertinggi kelima di dunia sebesar 24.208 bayi dengan nilai TFR (Total Fertility Rate) sebesar 2,32 di tahun 2015-2020, walaupun telah mengalami penurunan angka fertilitas, masih terdapat provinsi dengan TFR yang tinggi salah satunya provinsi Kalimantan Timur dengan TFR 2,7\% di tahun 2017 (SDKI, 2017).

Pada data SDKI 2017 di provinsi Kalimantan Timur pada data fertilitas terdapat faktor yang mempengaruhinya yaitu umur hubungan seksual pertama, umur pertama menikah, indeks kekayaan, lama penggunaan kontrasepsi, umur pertama melahirkan, jumlah anak ideal, dan jumlah kematian anak. Pada data yang mengandung multikolinieritas terjadi karena adanya korelasi antara variabel independen. Multikolinieritas pada data menyebabkan varian yang besar dan menghasilkan model dengan galat atau kesalahan yang besar. Oleh karena itu, pada penelitian ini dilakukan analisa mengenai penanggulangan masalah multikolinieritas sehingga diketahui determinan yang mempengaruhi fertilitas, deteksi multikolinieritas dan membuat model prediksi terbaik pada fertilitas wanita usia subur di Kalimantan Timur.

\section{METODE PENELITIAN}

Penelitian ini menggunakan data skunder dari Survei Demografi dan Kesehatan Indonesia (SDKI) tahun 2017 dengan desain penelitian crosssectional. Lokasi penelitian berfokus di provinsi Kalimantan Timur, dengan waktu Penelitian pada bulan Juni - Oktober 2020. Populasi merupakan keseluruhan unit analisis yang karakteristiknya akan diduga. Populasi dalam penelitian ini adalah wanita usia subur yang berusia 15-49 tahun di provinsi Kalimantan Timur, yang mengikuti Survei Demografi dan Kependudukan Indonesia (SDKI) tahun 2017 berjumlah 1221 WUS. Sampel yang akan digunakan dalam penelitian yaitu seluruh populasi penduduk wanita usia subur (15-49 tahun) yang memiliki status menikah dan terdata dalam SDKI 2017 di provinsi Kalimantan yaitu berjumlah 701 WUS. Analisis data menggunakan regresi linier berganda dengan metode kuadrat terkecil dan regresi ridge.

\section{HASIL DAN PEMBAHASAN}

\section{Distribusi Responden}

Tabel 1. Distribusi Responden (Wanita Usia Subur 15-49 tahun) SDKI 2017

\begin{tabular}{|c|c|c|}
\hline Variabel & Frekuensi (n) & Persentase $(\%)$ \\
\hline \multicolumn{3}{|c|}{ Jumlah Anak Lahir Hidup (Fertilitas) } \\
\hline 0 & 4 & 0,6 \\
\hline $1-2$ & 446 & 63,6 \\
\hline$>2$ & 251 & 35,8 \\
\hline Total & 701 & 100 \\
\hline \multicolumn{3}{|l|}{ Umur Seks Pertama } \\
\hline$<15$ & 51 & 7,3 \\
\hline $15-19$ & 299 & 42,7 \\
\hline $20-24$ & 254 & 36,2 \\
\hline$\geq 25$ & 97 & 13,8 \\
\hline Total & 701 & 100 \\
\hline \multicolumn{3}{|l|}{ Umur Kawin Pertama } \\
\hline$<15$ & 53 & 7,6 \\
\hline $15-19$ & 294 & 41,9 \\
\hline $20-24$ & 258 & 36,8 \\
\hline$\geq 25$ & 96 & 13,7 \\
\hline Total & 701 & 100 \\
\hline
\end{tabular}




\begin{tabular}{|c|c|c|}
\hline \multicolumn{3}{|l|}{ Umur Pertama Melahirkan } \\
\hline$<15$ & 15 & 2,1 \\
\hline $15-19$ & 232 & 33,1 \\
\hline $20-24$ & 294 & 41,9 \\
\hline$\geq 25$ & 160 & 22,8 \\
\hline Total & 701 & 100 \\
\hline \multicolumn{3}{|l|}{ Penggunaan Kontrasepsi } \\
\hline $\mathrm{Ya}$ & 489 & 69,8 \\
\hline Tidak & 212 & 30,2 \\
\hline Total & 701 & 100 \\
\hline \multicolumn{3}{|l|}{ Jumlah Anak Ideal } \\
\hline$\leq 2$ anak & 390 & 55,6 \\
\hline$>2$ anak & 311 & 44,4 \\
\hline Total & 701 & 100 \\
\hline \multicolumn{3}{|l|}{ Jumlah Kematian Anak } \\
\hline 0 anak & 639 & 91,2 \\
\hline 1 anak & 53 & 7,6 \\
\hline 2 anak & 8 & 1,1 \\
\hline$\geq 3$ anak & 1 & 0,1 \\
\hline Total & 701 & 100 \\
\hline \multicolumn{3}{|l|}{ Indeks Kekayaan } \\
\hline Terbawah & 34 & 4,9 \\
\hline Menengah Bawah & 117 & 16,7 \\
\hline Menengah & 186 & 26,5 \\
\hline Menengah Atas & 199 & 28,4 \\
\hline Teratas & 165 & 23,5 \\
\hline Total & 701 & 100 \\
\hline
\end{tabular}

Pada tabel 1 dapat diketahui bahwa WUS (15-49 tahun) di Kalimantan Timur memiliki jumlah anak lahir hidup 1-2 anak dengan pertama kali berhubungan seks dan menikah pada usia 1519 tahun. Umur pertama melahirkan pada kelompok usia 20-24 tahun dan sebagian besar telah menggunakan kontrasepsi. Lebih dari

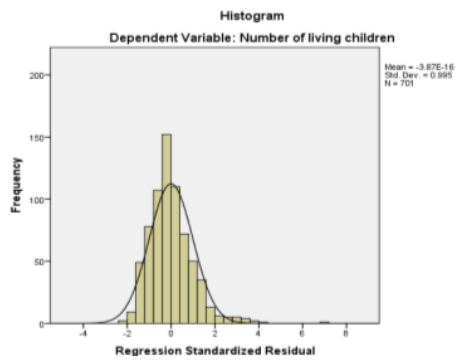

Gambar 1. Grafik Histogram Model Prediksi Fertilitas setengah WUS menginginkan jumlah anak $\leq 2$ anak dan sebagian besar WUS tidak pernah mengalami kematian anak dengan indeks kekayaan paling banyak pada kelompok menengah atas.

\section{Uji Asumsi Klasik}

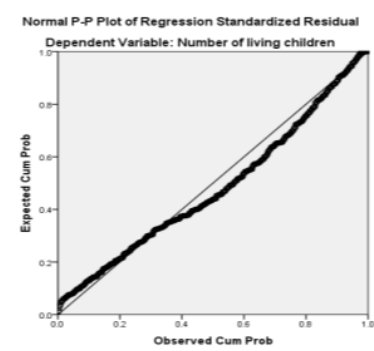

Gambar 2. Normal P-P Plot Model Prediksi Fertilitas

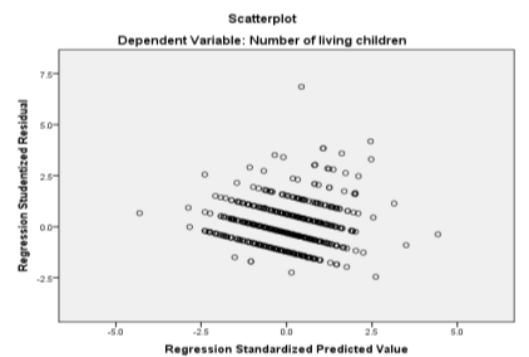

Gambar 3. Heteroskedastisitas Model Prediksi Fertilitas 
Penerapan model regresi sebagai model prediksi didapatkan dari hasil pemenuhan asumsi klasik regresi. Pada gambar 1 dan 2 di atas menunjukkan pola distribusi normal dan pola titik yang menyebar di sekitar grafik normal. Kedua gambar ini membuktikan bahwa model regresi memenuhi asumsi normalitas.
Pada gambar 3 plot terlihat mengelompok di suatu sisi atau titik-titik tersebut menyebar diatas dan dibawah angka 0 pada sumbu Y. Hal ini menunjukkan tidak terdapat gangguan heteroskedastisitas pada model regresi.

Tabel 2. Linearitas Model Tingkat Fertilitas

$$
\text { Model Tingkat Fertilitas }
$$

Tabel 3. Autokorelasi Model Prediksi Fertilitas

\begin{tabular}{ccc}
\hline \multicolumn{3}{c}{ Model Summary } \\
\hline Durbin Watson (DW) & Durbin Upper (DU) & $4-$ DU \\
1,919 & 1,89616 & 2,10384 \\
\hline
\end{tabular}

Tabel 4. Multikolinieritas Model Prediksi Fertilitas

\begin{tabular}{|c|c|c|}
\hline \multirow{2}{*}{ Variabel Prediktor BBL } & \multicolumn{2}{|c|}{ Colinearity Statistics } \\
\hline & Tolerance & VIF \\
\hline Umur Seks Pertama & 0,016 & 63,578 \\
\hline Umur Kawin Pertama & 0,015 & 67,339 \\
\hline Umur Pertama Melahirkan & 0,183 & 5,461 \\
\hline Lama Penggunaan Kontrasepsi & 0,949 & 1,054 \\
\hline Jumlah Anak Ideal & 0,965 & 1,036 \\
\hline Jumlah Kematian Anak & 0,948 & 1,055 \\
\hline Indeks Kekayaan & 0,940 & 1,064 \\
\hline
\end{tabular}

Tabel 2. memberikan informasi bahwa diperoleh nilai $\mathrm{p}$ dari uji $\mathrm{F}$ sebesar $<0,0001<0,05$ $(\alpha)$ hasil ini menunjukkan bahwa terbentuk hubungan linier dari gabungan variabel independen terhadap tingkat fertilitas di Provinsi Kalimantan Timur. Pada tabel 3 dapat dilihat bahwa Durbin Upper < Durbin Watson < 4 - Durbin Upper dimana hal ini menunjukkan bahwa tidak terdapat adanya gejala autokorelasi. Berdasarkan tabel 4 dapat dilihat bahwa model regresi mengalami gangguan multikolinieritas. Hal ini tampak pada nilai tolerance yang tidak mendekati 1 serta perhitungan VIF memiliki nilai $>10$. Jadi dapat disimpulkan bahwa terdapat gejala multikolinieritas antar variabel bebas dalam model regresi tersebut. Sehingga perlu dilakukan penggunaan metode regresi ridge untuk mengatasi masalah multikolinieritas tersebut.

\section{Regresi Linier Berganda}

Tabel 5. Model Regresi Linier Berganda

\begin{tabular}{|c|c|c|c|c|c|}
\hline Variabel & $\begin{array}{l}\text { Nilai p } \\
(\text { uji F })\end{array}$ & $\begin{array}{l}\text { Nilai p } \\
(\text { uji T) }\end{array}$ & Koefisien B & Beta & $\begin{array}{c}\text { Koefisien Determinasi } \\
\left(\mathbf{R}^{2}\right)\end{array}$ \\
\hline (konstan) & \multirow{8}{*}{$<0,0001$} & $<0,0001$ & 2,979 & & \multirow{8}{*}{0,154} \\
\hline Umur Seks Pertama & & 0,631 & $-0,037$ & $-0,134$ & \\
\hline Umur Kawin Pertama & & 0,626 & 0,038 & 0,140 & \\
\hline Umur Pertama Melahirkan & & 0,001 & $-0,075$ & $-0,283$ & \\
\hline Lama Penggunaan KB & & $<0,0001$ & 0,124 & 0,180 & \\
\hline Jumlah Anak Ideal & & $<0,0001$ & 0,220 & 0,221 & \\
\hline Jumlah Kematian Anak & & 0,119 & 0,188 & 0,056 & \\
\hline Indeks Kekayaan & & 0,933 & 5,456 & 0,003 & \\
\hline
\end{tabular}

Berdasarkan tabel 5, nilai p-value dari hasil uji $F$ sebesar $<0,0001$ yang menunjukkan bahwa ketujuh variabel independen tersebut secara simultan signifikan mempengaruhi jumlah anak lahir hidup. Dari hasil uji t didapatkan hanya variabel umur pertama melahirkan, lama KB dan 
jumlah anak ideal yang terbukti mempengaruhi secara signifikan pada jumlah anak lahir hidup. Model prediksi ini belum dapat digunakan dalam memperkirakan jumlah anak lahir hidup dikarenakan adanya multikolinieritas pada antar variabel yang menyebabkan interpretasi menjadi tidak sesuai. Sehingga perlu dilakukan pembentukan model dengan metode regresi ridge untuk mendapatkan hasil pemodelan yang lebih baik.

\section{Regresi Ridge}

Tabel 6. Nilai VIF $\widehat{\boldsymbol{\beta}}(\mathrm{c})$ dengan berbagai nilai c

\begin{tabular}{|c|c|c|c|c|c|c|c|}
\hline Nilai c & $\begin{array}{c}\mathrm{USP} \\
\operatorname{VIF} \widehat{\boldsymbol{\beta}}_{1}(\mathrm{c})\end{array}$ & $\begin{array}{c}\text { UKP } \\
\text { VIF } \widehat{\boldsymbol{\beta}}_{2}(\mathrm{c})\end{array}$ & $\begin{array}{c}\mathrm{UPM} \\
\operatorname{VIF} \widehat{\boldsymbol{\beta}}_{3}(\mathrm{c})\end{array}$ & $\begin{array}{c}\mathrm{LKB} \\
\operatorname{VIF} \widehat{\boldsymbol{\beta}}_{4}(\mathrm{c})\end{array}$ & $\begin{array}{c}\text { JAI } \\
\operatorname{VIF} \widehat{\boldsymbol{\beta}}_{5}(\mathrm{c})\end{array}$ & $\begin{array}{c}\text { JKA } \\
\operatorname{VIF} \widehat{\boldsymbol{\beta}}_{6}(\mathrm{c})\end{array}$ & $\frac{\mathrm{IK}}{\operatorname{VIF} \widehat{\boldsymbol{\beta}}_{7}(\mathrm{c})}$ \\
\hline 0 & 63,5771 & 67,33918 & 5,460902 & 1,053738 & 1,036208 & 1,054677 & 1,063858 \\
\hline 0,0001 & 62,0120 & 65,67326 & 5,450646 & 1,053491 & 1,035875 & 1,054423 & 1,063477 \\
\hline 0,0002 & 60,5052 & 64,06941 & 5,440488 & 1,053245 & 1,035547 & 1,05417 & 1,063101 \\
\hline 0,0003 & 59,0538 & 62,52458 & 5,430424 & 1,052999 & 1,035222 & 1,053917 & 1,062731 \\
\hline 0,0004 & 57,6551 & 61,03589 & 5,42045 & 1,052754 & 1,034902 & 1,053666 & 1,062366 \\
\hline 0,0005 & 56,3067 & 59,60067 & 5,410564 & 1,052509 & 1,034585 & 1,053415 & 1,062006 \\
\hline 0,0006 & 55,0061 & 58,21637 & 5,400761 & 1,052263 & 1,034272 & 1,053165 & 1,06165 \\
\hline 0,0007 & 53,7511 & 56,88063 & 5,391038 & 1,052019 & 1,033962 & 1,052915 & 1,061299 \\
\hline 0,0008 & 52,5395 & 55,59118 & 5,381394 & 1,051774 & 1,033656 & 1,052667 & 1,060952 \\
\hline 0,0009 & 51,3695 & 54,34591 & 5,371824 & 1,05153 & 1,033352 & 1,052418 & 1,060609 \\
\hline 0,001 & 50,2391 & 53,14282 & 5,362327 & 1,051286 & 1,033051 & 1,052171 & 1,06027 \\
\hline 0,002 & 40,7681 & 43,06372 & 5,270841 & 1,048858 & 1,030183 & 1,049724 & 1,05706 \\
\hline 0,003 & 33,8001 & 35,6497 & 5,184535 & 1,04645 & 1,027503 & 1,04732 & 1,054096 \\
\hline 0,004 & 28,5238 & 30,03665 & 5,10225 & 1,044057 & 1,024953 & 1,044946 & 1,051302 \\
\hline 0,005 & 24,4315 & 25,6843 & 5,023245 & 1,041679 & 1,022496 & 1,042597 & 1,048629 \\
\hline 0,006 & 21,1930 & 22,24082 & 4,947022 & 1,039313 & 1,020107 & 1,040267 & 1,046046 \\
\hline 0,007 & 18,5854 & 19,46906 & 4,87323 & 1,03696 & 1,017772 & 1,037954 & 1,043531 \\
\hline 0,008 & 16,4543 & 17,20451 & 4,801614 & 1,034618 & 1,015478 & 1,035657 & 1,041069 \\
\hline 0,009 & 14,6897 & 15,33009 & 4,731978 & 1,032288 & 1,013218 & 1,033372 & 1,03865 \\
\hline 0,01 & 13,2117 & 13,7607 & 4,664174 & 1,029968 & 1,010985 & 1,0311 & 1,036266 \\
\hline 0,02 & 6,02861 & 6,151392 & 4,067357 & 1,00731 & 0,989585 & 1,008929 & 1,013571 \\
\hline 0,03 & 3,66133 & 3,662615 & 3,583948 & 0,985544 & 0,969194 & 0,987601 & 0,992068 \\
\hline 0,04 & 2,56802 & 2,524845 & 3,184652 & 0,964590 & 0,949526 & 0,967018 & 0,971381 \\
\hline 0,05 & 1,95889 & 1,898329 & 2,850543 & 0,944387 & 0,930497 & 0,947128 & 0,951399 \\
\hline 0,06 & 1,57648 & 1,509818 & 2,568008 & 0,924885 & 0,912062 & 0,927887 & 0,932067 \\
\hline 0,07 & 1,31592 & 1,248312 & 2,326882 & 0,906042 & 0,894191 & 0,909261 & 0,913345 \\
\hline 0,08 & 1,1276 & 1,061503 & 2,11941 & 0,887819 & 0,876856 & 0,891219 & 0,895204 \\
\hline 0,09 & 0,98537 & 0,921942 & 1,93958 & 0,870184 & 0,860035 & 0,873733 & 0,877615 \\
\hline 0,1 & 0,87426 & 0,814002 & 1,782671 & 0,853107 & 0,843705 & 0,856777 & 0,860553 \\
\hline 0,2 & 0,40523 & 0,372002 & 0,912881 & 0,707954 & 0,703586 & 0,711902 & 0,714637 \\
\hline 0,3 & 0,26365 & 0,243674 & 0,571834 & 0,597965 & 0,596161 & 0,601447 & 0,603340 \\
\hline 0,4 & 0,19749 & 0,184367 & 0,402149 & 0,512294 & 0,511882 & 0,515134 & 0,516402 \\
\hline 0,5 & 0,15965 & 0,150450 & 0,304600 & 0,444125 & 0,444481 & 0,446337 & 0,447149 \\
\hline 0,6 & 0,13516 & 0,128396 & 0,242758 & 0,388920 & 0,389696 & 0,390583 & 0,391063 \\
\hline 0,7 & 0,11792 & 0,112763 & 0,200672 & 0,343546 & 0,344538 & 0,344750 & 0,344987 \\
\hline 0,8 & 0,10503 & 0,10098 & 0,170453 & 0,305772 & 0,306861 & 0,306601 & 0,306662 \\
\hline 0,9 & 0,09494 & 0,091688 & 0,147823 & 0,273971 & 0,275089 & 0,274509 & 0,274434 \\
\hline 1 & 0,08676 & 0,084108 & 0,130296 & 0,246937 & 0,248040 & 0,247228 & 0,247069 \\
\hline
\end{tabular}


Sebelum membentuk pemodelan regresi ridge, perlu dilakukan transformasi data dengan pemusatan dan penskalaan (centering and rescaling) untuk meminumkan kesalahan. Dari tabel 6 diatas dapat dilihat bahwa terdapat tetapan bias $\mathrm{c}=0,000$ sampai dengan $\mathrm{c}=1,000$, dengan nilai VIF koefisien estimator $\widehat{\beta}(\mathrm{c})$ yang semakin mengecil. Nilai VIF yang akan diambil adalah VIF yang stabil yaitu $<10$ serta relatif dekat dengan satu.

Tabel 7. Nilai $\widehat{\boldsymbol{\beta}}(\mathrm{c})$ dengan berbagai tetapan bias $\mathrm{c}$

\begin{tabular}{|c|c|c|c|c|c|c|c|}
\hline Nilai c & $\begin{array}{c}\text { USP } \\
\widehat{\boldsymbol{\beta}}_{1}(\mathrm{c}) \\
\end{array}$ & $\begin{array}{l}\text { UKP } \\
\widehat{\boldsymbol{\beta}}_{2}(\mathrm{c})\end{array}$ & $\begin{array}{l}\text { UPM } \\
\widehat{\boldsymbol{\beta}}_{3}(\mathrm{c}) \\
\end{array}$ & $\begin{array}{l}\text { LKB } \\
\widehat{\boldsymbol{\beta}}_{4}(\mathrm{c})\end{array}$ & $\begin{array}{c}\text { JAI } \\
\widehat{\boldsymbol{\beta}}_{5}(\mathrm{c}) \\
\end{array}$ & $\begin{array}{c}\text { JKA } \\
\hat{\boldsymbol{\beta}}_{6}(\mathrm{c}) \\
\end{array}$ & $\begin{array}{c}\text { IK } \\
\widehat{\boldsymbol{\beta}}_{7}(\mathrm{c}) \\
\end{array}$ \\
\hline 0 & $-0,1334847$ & 0,139397 & $-0,282747$ & 0,180509 & 0,220921 & 0,0559017 & 0,0030123 \\
\hline 0,0001 & $-0,1317974$ & 0,137523 & $-0,282538$ & 0,180487 & 0,220912 & 0,0558941 & 0,0029930 \\
\hline 0,0002 & $-0,1301539$ & 0,135695 & $-0,282330$ & 0,180466 & 0,220902 & 0,0558868 & 0,0029741 \\
\hline 0,0003 & $-0,1285526$ & 0,133911 & $-0,282124$ & 0,180444 & 0,220892 & 0,0558795 & 0,0029556 \\
\hline 0,0004 & $-0,126992$ & 0,132169 & $-0,281919$ & 0,180422 & 0,220881 & 0,0558724 & 0,0029375 \\
\hline 0,0005 & $-0,1254705$ & 0,130468 & $-0,281717$ & 0,180401 & 0,220870 & 0,0558655 & 0,0029197 \\
\hline 0,0006 & $-0,1239868$ & 0,128805 & $-0,281516$ & 0,180379 & 0,220859 & 0,0558587 & 0,0029024 \\
\hline 0,0007 & $-0,1225395$ & 0,127181 & $-0,281316$ & 0,180358 & 0,220847 & 0,0558520 & 0,0028854 \\
\hline 0,0008 & $-0,1211274$ & 0,125593 & $-0,281118$ & 0,180337 & 0,220835 & 0,0558454 & 0,0028688 \\
\hline 0,0009 & $-0,1197492$ & 0,124040 & $-0,280922$ & 0,180315 & 0,220823 & 0,0558390 & 0,0028524 \\
\hline 0,001 & $-0,1184038$ & 0,122522 & $-0,280727$ & 0,180294 & 0,220810 & 0,0558326 & 0,0028364 \\
\hline 0,002 & $-0,1065307$ & 0,108978 & $-0,278846$ & 0,180085 & 0,220672 & 0,0557746 & 0,0026917 \\
\hline 0,003 & $-0,0969711$ & 0,097841 & $-0,277072$ & 0,179878 & 0,220515 & 0,0557246 & 0,0025694 \\
\hline 0,004 & $-0,0891341$ & 0,088502 & $-0,275382$ & 0,179677 & 0,220343 & 0,0556802 & 0,0024639 \\
\hline 0,005 & $-0,0826137$ & 0,080541 & $-0,273762$ & 0,179478 & 0,220160 & 0,0556402 & 0,0023711 \\
\hline 0,006 & $-0,0771215$ & 0,073660 & $-0,272199$ & 0,179279 & 0,219969 & 0,0556035 & 0,0022882 \\
\hline 0,007 & $-0,0724473$ & 0,067641 & $-0,270685$ & 0,179083 & 0,219771 & 0,0555693 & 0,0022132 \\
\hline 0,008 & $-0,0684339$ & 0,062323 & $-0,269215$ & 0,178887 & 0,219568 & 0,0555371 & 0,0021445 \\
\hline 0,009 & $-0,0649621$ & 0,057582 & $-0,267784$ & 0,178692 & 0,219361 & 0,0555065 & 0,0020811 \\
\hline 0,01 & $-0,0619391$ & 0,053320 & $-0,266387$ & 0,178498 & 0,219150 & 0,0554770 & 0,0020219 \\
\hline 0,02 & $-0,0455605$ & 0,025885 & $-0,253850$ & 0,176579 & 0,216944 & 0,0552137 & 0,0015613 \\
\hline 0,03 & $-0,0400219$ & 0,011026 & $-0,243165$ & 0,174682 & 0,214684 & 0,0549607 & 0,0012018 \\
\hline 0,04 & $-0,0381948$ & 0,001142 & $-0,233812$ & 0,172801 & 0,212432 & 0,0546989 & 0,0008768 \\
\hline 0,05 & $-0,0379444$ & $-0,00616$ & $-0,225514$ & 0,170938 & 0,210206 & 0,0544259 & 0,0005676 \\
\hline 0,06 & $-0,0384333$ & $-0,01190$ & $-0,218083$ & 0,169096 & 0,208014 & 0,0541427 & 0,0002678 \\
\hline 0,07 & $-0,0392791$ & $-0,01660$ & $-0,211378$ & 0,167276 & 0,205860 & 0,0538511 & $-2,507161$ \\
\hline 0,08 & $-0,0402902$ & $-0,02054$ & $-0,205292$ & 0,165481 & 0,203744 & 0,0535529 & $-0,000312$ \\
\hline 0,09 & $-0,0413650$ & $-0,02391$ & $-0,199736$ & 0,163713 & 0,201667 & 0,0532496 & $-0,000593$ \\
\hline 0,1 & $-0,0424477$ & $-0,02684$ & $-0,194640$ & 0,161971 & 0,199629 & 0,0529428 & $-0,000870$ \\
\hline 0,2 & $-0,0508438$ & $-0,04348$ & $-0,159739$ & 0,146087 & 0,181237 & 0,0498628 & $-0,003310$ \\
\hline 0,3 & $-0,0551507$ & $-0,05040$ & $-0,139819$ & 0,132784 & 0,165918 & 0,0470062 & $-0,005201$ \\
\hline 0,4 & $-0,0572330$ & $-0,05373$ & $-0,126501$ & 0,121591 & 0,152991 & 0,0444538 & $-0,006646$ \\
\hline 0,5 & $-0,0581130$ & $-0,05533$ & $-0,116723$ & 0,112079 & 0,141941 & 0,0421842 & $-0,007746$ \\
\hline 0,6 & $-0,0583005$ & $-0,05599$ & $-0,109090$ & 0,103911 & 0,132389 & 0,0401594 & $-0,008585$ \\
\hline 0,7 & $-0,0580692$ & $-0,05609$ & $-0,102872$ & 0,096827 & 0,124049 & 0,0383431 & $-0,009224$ \\
\hline 0,8 & $-0,0575765$ & $-0,05585$ & $-0,097646$ & 0,090629 & 0,116704 & 0,0367038 & $-0,009708$ \\
\hline 0,9 & $-0,0569181$ & $-0,05538$ & $-0,093151$ & 0,085163 & 0,110185 & 0,0352159 & $-0,010072$ \\
\hline 1 & $-0,0561547$ & $-0,05476$ & $-0,089214$ & 0,080309 & 0,104361 & 0,0338582 & $-0,010342$ \\
\hline
\end{tabular}


Pada tabel 7 dapat dilihat berbagai nilai tetapan bias c, atas dasar koefisien estimator maka

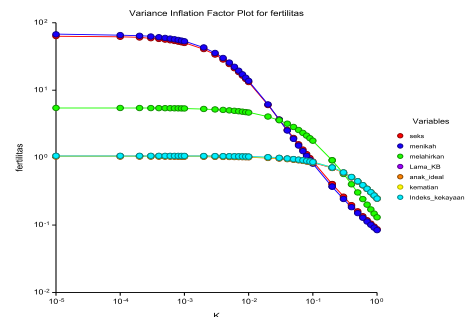

Gambar 4. VIF Plot

Pada gambar 4 diketahui nilai VIF mulai menunjukkan adanya penurunan VIF dari setiap koefisien $\widehat{\beta}$ (c) menuju nilai 0 . Tetapan bias $\mathrm{c}$ ini memberikan nilai seluruh variabel yang kurang dari 10, yaitu pada $\mathrm{c}=0,2$ ini menunjukkan bahwa nilai VIF mendekati 1 dari 0 sehingga koefisien $\widehat{\beta}$ lebih stabil. Pada gambar 5 ridge trace menunjukkan grafik yang stabil, selain itu dari dapat dibentuk suatu gambar ridge trace.

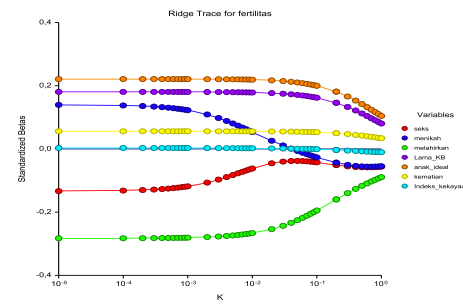

Gambar 5. Ridge Trace

berbagai tetapan bias c. Persamaan regresi yang diperoleh jika $\mathrm{c}=0,2$ adalah sebagai berikut:

$\widehat{Y}^{\mathrm{R}}=-0,0508438$ Umur Seks - 0,04348 Umur Kawin - 0,159739 Umur Melahirkan + 0,146087 Lama KB + 0,181237 Anak Ideal + 0,0498628 Kematian Anak - 0,0033010 Indeks Kekayaan

Tabel 8. ANOVA Ridge

\begin{tabular}{ccccccc}
\hline Varian & $\begin{array}{c}\text { Jumlah } \\
\text { Kuadrat }\end{array}$ & DK & $\begin{array}{c}\text { Rata-rata Jumlah } \\
\text { Kuadrat }\end{array}$ & F hitung & Sig & $R^{2}$ \\
\hline Sisa & 1 & 3794,809 & 3794,809 & & & \\
Regresi & 7 & 128,5387 & 18,36267 & 14,9069 & $<0,001$ & 0,1308 \\
Error & 693 & 853,6525 & 1,231822 & & & \\
Total & 700 & 982,1912 & 1,40313 & & & \\
\hline
\end{tabular}

Kemudian akan diuji keberartian dari model tersebut, Pada tabel 8 didapatkan nilai Sig < 0,001 , dapat dinyatakan bahwa terdapat hubungan linier antara variabel independen dengan variabel dependen. Nilai $\mathrm{R}^{2}$ untuk variabel fertilitas sebesar
0,1308 . Hal ini berarti variabel fertilitas dapat dijelaskan oleh variabel sebesar $13 \%$, sisanya $87 \%$ variabel dapat dijelaskan oleh faktor lainnya yang tidak terjelaskan dalam model.

Tabel 9. Uji T

\begin{tabular}{|c|c|c|c|c|c|}
\hline Variabel & $b_{i}$ & $\mathrm{~S}\left\{\mathrm{~b}_{\mathrm{i}}\right\}$ & $\left|t_{\text {hitung }}\right|$ & $\mathrm{t}_{\text {tabel }}$ & Kesimpulan \\
\hline Umur Seks Pertama & $-0,0508438$ & 0,006238114 & $-8,15051$ & \multirow{7}{*}{1,65} & Signifikan \\
\hline Umur Kawin Pertama & $-0,04348$ & 0,005925746 & $-7,33739$ & & Signifikan \\
\hline Umur Pertama Melahirkan & $-0,159739$ & 0,008967094 & $-17,8139$ & & Signifikan \\
\hline Lama Penggunaan Kontrasepsi & 0,146087 & 0,02043124 & 7,15017 & & Signifikan \\
\hline Jumlah Anak Ideal & 0,181237 & 0,02954383 & 6,13450 & & Signifikan \\
\hline Jumlah Kematian Anak & 0,0498628 & 0,1006267 & 0,49552 & & Tidak Signifikan \\
\hline Indeks Kekayaan & $-0,003310$ & $0,0,5371607$ & $-0,06161$ & & Tidak Signifikan \\
\hline
\end{tabular}


Pada tabel 10 menunjukkan variabel independen yaitu umur seks pertama, umur kawin pertama, umur pertama melahirkan, lama penggunaan kontrasepsi dan jumlah anak ideal secara parsial berpengaruh signifikan terhadap variabel jumlah anak lahir hidup. Sedangkan variabel jumlah kematian anak dan indeks kekayaan secara parsial tidak berhubungan signifikan terhadap variabel jumlah anak lahir hidup. Setelah dilakukan uji parsial regresi ridge, maka model regresi ridge akan ditransformasi ke bentuk awal dan didapatkan permodelan regresi linier berganda dengan metode ridge.

Tabel 10. Perbandingan Nilai VIF

\begin{tabular}{ccc}
\hline \multirow{2}{*}{ Variabel } & \multicolumn{2}{c}{ Nilai VIF } \\
\cline { 2 - 3 } & MKT & Ridge \\
\hline Seks & 63,578 & 0,4052335 \\
Menikah & 67,339 & 0,3720023 \\
Melahirkan & 5,461 & 0,9128808 \\
Lama KB & 1,054 & 0,7079542 \\
Anak ideal & 1,036 & 0,7035857 \\
Kematian & 1,055 & 0,7119023 \\
Indeks kekayaan & 1,064 & 0,7146372 \\
\hline
\end{tabular}

Tabel 11. Hasil Perbandingan MKT dan Regresi Ridge

\begin{tabular}{ccccc}
\hline \multirow{2}{*}{ Variabel } & \multicolumn{2}{c}{ Estimasi Parameter } & \multicolumn{2}{c}{ Standar error } \\
\cline { 2 - 5 } & MKT & Ridge & MKT & Ridge \\
\hline Intercept & 2,979 & 2,995148 & & \\
Seks & $-0,037$ & $-0,01406898$ & 0,077 & 0,006238114 \\
Menikah & 0,038 & $-0,0119283$ & 0,079 & 0,005925746 \\
Melahirkan & $-0,075$ & $-0,04233311$ & 0,022 & 0,008967094 \\
Lama KB & 0,124 & 0,1001676 & 0,025 & 0,02043124 \\
Anak ideal & 0,220 & 0,1802514 & 0,035 & 0,02954383 \\
Kematian & 0,188 & 0,1679205 & 0,121 & 0,1006267 \\
Indeks kekayaan & 5,456 & $-0,0059382$ & 0,065 & 0,05371607 \\
\hline
\end{tabular}

Untuk mendapatkan model terbaik maka akan dilakukan perbandingan pada metode MKT dan ridge. Pada tabel 11 metode regresi ridge nilai VIF seluruh variabel independen dibawah 1 atau kurang dari 10, hal ini menunjukkan bahwa masalah multikolinieritas teratasi setelah dianalisis menggunakan metode regresi ridge. Tabel 12 menunjukkan dengan menggunakan regresi ridge menghasilkan standar error yang lebih kecil oleh karena itu regresi ridge lebih baik dibandingkan metode kuadrat terkecil dalam mengatasi multikolinieritas. Setelah dilakukan perbandingan standard error, maka didapatkan permodelan regresi berganda untuk masing-masing metode sebagai berikut:

Metode Kuadrat Terkecil (MKT)

$$
\begin{aligned}
\mathrm{Y}= & 2,979-0,037 \text { (umur seks pertama) }+0,038 \\
& \text { (umur kawin pertama) - 0,075 (umur pertama } \\
& \text { melahirkan) }+0,124 \text { (lama kontasepsi) + } \\
& 0,220 \text { (jumlah anak ideal) }+0,188 \text { (kematian } \\
& \text { anak) }+5,456 \text { (Indeks kekayaan) }
\end{aligned}
$$

Metode Regresi Ridge

$\mathrm{Y}^{\mathrm{R}}=2,995148-0,01406898$ (umur seks pertama) - 0,0119283 (umur kawin pertama) 0,04233311 (umur pertama melahirkan) + 0,1001676 (lama kontasepsi) + 0,1802514 (jumlah anak ideal) $+0,1679205$ (kematian anak) - 0,005938239 (Indeks kekayaan)

Model yang dihasilkan akan diaplikasikan untuk memprediksi tingkat fertilitas atau jumlah anak lahir hidup yang dimiliki wanita usia subur dengan menggunakan faktor-faktor yang mempengaruhinya. Berikut simulasi prediksi tingkat fertilitas pada wanita usia subur (15-49 tahun):

1) Sampel ke-1

Data SDKI $=3$

Metode Kuadrat Terkecil

$$
\begin{aligned}
\text { Fertilitas }= & 2,979-0,037(23)+0,038(23)- \\
& 0,075(24)+0,124(3,9)+0,220(3) \\
& +0,188(0)+5,456(0,21042)=3,5
\end{aligned}
$$


Metode Regresi Ridge

$$
\begin{aligned}
\text { Fertilitas }= & 2,995148-0,01406898(23)- \\
& 0,0119283(23)-0,04233311(24) \\
& +0,1001676(3,9)+0,1802514(3) \\
& +0,1679205(0)-0,005938239 \\
& (0,21042)=2,3
\end{aligned}
$$

2) Sampel ke-184

Data SDKI $=2$

Metode Kuadrat Terkecil

$$
\begin{aligned}
& \text { Fertilitas }= 2,979-0,037(19)+0,038(24)- \\
& 0,075(41)+0,124(0)+0,220 \\
&(4)+0,188(0)+5,456(1,13868) \\
&= 7,2 \\
& \text { Metode Regresi Ridge } \\
& \text { Fertilitas }= 2,995148-0,01406898(19)- \\
& 0,0119283(24)-0,04233311(41) \\
&+0,1001676(0)+0,1802514(4) \\
&+0,1679205(0)-0,005938239 \\
&(1,13868)=1,4
\end{aligned}
$$

Berdasarkan hasil perhitungan menunjukkan bahwa prediksi tingkat fertilitas WUS dengan menggunakan metode regresi ridge memberikan hasil yang lebih baik ditandai dengan nilai standar error yang lebih kecil serta pemodelan yang lebih tepat digunakan untuk memperkirakan jumlah anak lahir hidup daripada menggunakan MKT.

Umur seksual pertama pada beberapa WUS dimulai dari umur terendah yaitu 15 tahun, pada usia ini WUS masih berada pada usia remaja maupun pranikah. Perubahan sosial menuju masyarakat modern menyebabkan terjadinya hubungan seksual pra nikah yang beresiko pada kehamilan usia dini (Rahman dan Muslimin, 2020). Perilaku seksual pranikah yang buruk akan beresiko 10 kali lebih besar untuk terjadi kehamilan dibandingkan dengan perilaku seksual pranikah yang baik (Rahman dan Muslimin, 2020).

Berdasarkan hasil penelitian ini menunjukkan hubungan yang signifikan dan negatif $(-8,15051>1,65)$ antara umur seks pertama dengan tingkat fertilitas di Kalimantan Timur. Hal ini sejalan dengan penelitian Arsyad dan Nurhayati (2016) yang menyatakan umur seks pertama yang dimulai pada usia yang lebih muda cenderung akan memiliki $>2$ anak dibandingkan WUS yang umur pertama seksual pada usia lebih tua. Pada WUS yang memulai hubungan seksual pada usia yang lebih tua memiliki kematangan emosi dan pengetahuan yang cukup mengenai kesehatan reproduksi daripada remaja. Sehingga tingkat emosi yang labil dan kurangnya pengetahuan dapat menyebabkan resiko kehamilan dan kelahiran yang tinggi pada usia dini (Nasution, 2012).
Umur kawin pertama dapat memberikan kontribusi terhadap angka kelahiran, dengan melihat rata-rata umur kawin pertama dapat menentukan tinggi rendahnya fertilitas. Umur kawin pertama yang rendah dapat beresiko terhadap kesiapan mental untuk membina rumah tangga, kehamilan usia muda serta dapat menimbulkan kematian pada ibu maupun bayi yang dilahirkan (Sinaga, Hardiani dan Prihanto, 2017).

Berdasarkan hasil penelitian ini ditemukan bahwa terdapat hubungan atau pengaruh yang signifikan dan negatif antara umur kawin pertama dengan fertilitas di provinsi Kalimantan Timur ($7,33739>1,65)$, artinya apabila wanita usia subur menikah pada usia dini maka akan meningkatkan fertilitas karena masa kesempatan reproduksi yang lebih panjang. Hasil yang serupa juga ditemui pada penelitian Yuniarti dan Setiowati (2015) yang menyebutkan bahwa umur kawin pertama berhubungan secara signifikan dengan tingkat fertilitas dan menunjukkan bahwa dengan semakin rendah usia kawin pertama maka akan memerpanjang masa reproduksi serta meningkatkan resiko wanita usia subur untuk hamil dan melahirkan anak lahir hidup. Semakin rendah umur kawin pertama maka akan melahirkan anak yang semakin banyak begitupun sebaliknya (Pratama, Trisnaningsih dan Zulkarnain, 2017).

Seorang wanita pada masa usia subur yang melahirkan pada umur muda cenderung memiliki resiko kesehatan yang lebih tinggi (Cicih, 2019). Rata-rata umur pada kelahiran anak pertama mempengaruhi tingkat fertilitas. Wanita yang menikah di umur muda lebih lama menghadapi resiko kehamilan yang tentu saja menghasilkan jumlah anak yang banyak dan memiliki resiko kesehatan yang tinggi. (Pontoh, 2018).

Hasil analisis yang telah dilakukan membuktikan bahwa umur pertama melahirkan memiliki pengaruh yang signifikan dan negatif ($17,8139>1,65)$ dengan tingkat fertilitas di Kalimantan Timur dengan rata-rata umur pertama melahirkan pada usia 22 tahun, yang merupakan usia yang baik untuk melahirkan, sehingga meningkatkan tingkat keberhasilan dalam melahirkan. Hal ini dapat berakibat terhadap peningkatan jumlah anak lahir hidup atau fertilitas di Kalimantan Timur.

Hal ini serupa dengan penelitian yang dilakukan Zulkifli, Amri dan Munawar, (2020) yang membuktikan bahwa umur pertama melahirkan berpengaruh negatif dan signifikan sehingga semakin tinggi usia melahirkan WUS, maka fertilitas menurun karena rentang waktu 
subur untuk melahirkan semakin kecil. Umur 1834 tahun merupakan rentang umur yang beresiko rendah, oleh karena itu tingkat fertilitas akan turun jika usia melahirkan pertama meningkat.

Lama penggunaan kontrasepsi atau lama WUS menggunakan kontrasepsi (tahun) merupakan salah satu faktor yang berpengaruh signifikan negatif terhadap tingkat fertilitas. Penggunaan alat kontrasepsi dalam jangka waktu yang lama secara langsung akan membatasi tingkat fertilitas, sehingga jumlah anak yang dilahirkan lebih sedikit (Adi, 2013).

Hasil analisis membuktikan bahwa lama penggunaan kontrasepsi berpengaruh signifikan $(7,15017>1,65)$ dengan tingkat fertilitas. Hal ini sejalan dengan penelitian yang mengemukakan bahwa terdapat hubungan yang signifikan positif antara lama penggunaan kontrasepsi dengan jumlah anak hidup yang artinya semakin lama penggunaan kontrasepsi maka jumlah anak lahir hidup akan meningkat. Namun, adanya pengaruh positif ini dapat terjadi karena umur perkawinan pertama yang rendah, sehingga lama penggunaan kontrasepsi cenderung lebih panjang daripada WUS yang menikah di usia lebih tua. Perkawinan di usia muda dapat memberikan resiko melahirkan yang lebih besar walaupun telah menggunakan kontrasepsi cukup lama dikarenakan masa subur yang relatif lebih panjang (Saskara dan Marhaeni, 2015). Kontrasepsi jangka pendek dapat memberikan resiko kehamilan yang lebih tinggi dibandingkan kontrasepsi jangka panjang seperti implant atau IUD. Sehingga lama penggunaan alat kontrasepsi ini juga berkaitan dengan umur pertama menggunakan kontrasepsi, jenis kontrasepsi dan jumlah anak saat memulai KB (Saraswati, Trisnaningsih dan Zulkarnain, 2018).

Jumlah anak ideal merupakan banyaknya anak yang diinginkan oleh WUS sepanjang masa hidupnya. Jumlah anak ideal memberikan pengaruh positif pada tingkat fertilitas, semakin banyak jumlah anak ideal maka semakin banyak pula jumlah anak yang dilahirkan. Jumlah anak lahir akan terus bertambah hingga suatu keluarga telah mencapai ukuran keluarga yang diinginkan (Oktriyanto, Puspitawati dan Muflikhati, 2015).

Hasil penelitian yang telah dilakukan, menunjukkan bahwa terdapat hubungan yang signifikan $(6,13450>1,65)$ antara jumlah anak ideal dengan jumlah anak lahir hidup di Kalimantan Timur. Hasil penelitian ini sejalan dengan penelitian Sunaryanto (2012) yang menyebutkan bahwa fertilitas dipengaruhi oleh jumlah anak ideal dalam keluarga, dimana jumlah anak ideal sebesar 2,4 sedangkan jumlah anak lahir hidup sebesar 2,8. Hal ini menunjukkan bahwa peningkatan fertilitas mengikuti pola peningkatan jumlah anak ideal.

Faktor budaya dan lingkungan mempengaruhi keinginan memiliki anak salah satunya norma jenis kelamin anak yang diharapkan orangtua. Jika jenis kelamin memiliki pandangan yang sama maka keinginan untuk memiliki jumlah anak ideal akan berkurang karena telah tercapainya kepuasan besar keluarga tanpa melihat jenis kelamin anak. Dalam suatu lingkungan apabila memiliki anak $>2$ orang anak maka kecendrungan WUS untuk menginginkan > 2 anak akan semakin besar karena telah menjadi kebiasaan dilingkungan tersebut yang dapat menyumbang peningkatan fertilitas (Cenia, 2017).

Kematian anak menjadi faktor yang berkontribusi dalam peningkatan fertilitas. Semakin banyak anak meninggal yang dialami WUS maka tingkat kelahiran akan meningkat. Kematian bayi berpengaruh terhadap kesuburan ibu dan psikologi keluarga, WUS akan cenderung memiliki anak banyak sebagai pengganti apabila terjadi kematian (Arsyad dan Nurhayati, 2016).

Berdasarkan hasil penelitian ini diketahui bahwa tidak terdapat hubungan yang signifikan $(0,49552<1,65)$ antara jumlah kematian anak dengan tingkat fertilitas. Hal ini sejalan dengan penelitian Hanum dan Andiny (2018) yang menyatakan bahwa tidak terdapat pengaruh yang signifikan antara kematian anak dengan tingkat fertilitas. Hal ini menunjukkan bahwa kematian anak bukan satu-satunya faktor yang mempengaruhi fertlitas di Kalimantan Timur. Pengalaman kematian anak memberikan dampak trauma pada WUS, dimana masing-masing wanita memiliki perbedaan dalam menghadapi trauma kehilangan anak. Rasa bersalah dan trauma yang dihadapi WUS terjadi karena ketidakmampuan untuk melakukan sesuatu yang dapat mencegah kematian anak. Sehingga orangtua tidak memperhatikan jumlah anak yang dimiliki melainkan berusaha untuk mengurangi resiko kematian pada anak lainnya (Yuniarti dan Setiowati, 2015).

Dengan melahirkan anak kembali tidak dapat menghilangkan rasa kehilangan yang dialami WUS karena dibutuhkan waktu untuk menyadari dan menerima fakta dalam hidupnya serta kesedihan juga tidak dapat hilang seluruhnya. Ibu yang mengalami kematian anak membuntuhkan dukungan dari keluarga untuk memulihkan trauma kehilangan yang dirasakan (Winta dan Syafitri, 2019). 
Indeks kekayaan dapat mencerminkan status kesejahteraan secara ekonomi. Semakin tinggi kesejahteraan keluarga maka akan memperkecil persentase kejadian fertilitas (Raharja, 2014). Pada keluarga dengan indeks kekayaan tinggi akan kurang menginginkan anak lagi dibandingkan dengan indeks kekayaan dibawahnya. Kehadiran seorang anak dapat dilihat dari segi utilitas dan ekonomi bagi orangtuanya. Pada status ekonomi menengah dan tinggi akan mempertimbangkan kualitas anak daripada kuantitas sehingga tingkat fertilitas menjadi lebih rendah. Sedangkan pada status ekonomi yang rendah dengan memiliki anak, orangtua akan mendapatkan keuntungan jika anak tersebut bekerja di kemudian hari (Sari, 2017).

Berdasarkan hasil analisis membuktikan bahwa tidak terdapat hubungan yang signifikan ($0,06161<1,65)$ antara indeks kekayaan dengan tingkat fertilitas. Penelitian ini sejalan dengan penelitian Zulkifli, Amri dan Munawar (2020) yang menunjukkan hubungan negatif serta tidak signifikan terhadap tingkat fertilitas WUS di provinsi Aceh.

Hal ini menunjukkan bahwa indeks kekayaan bukan satu-satunya faktor yang mempengaruhi tigkat fertilitas di Kalimantan Timur. Selain itu, tidak adanya hubungan antara indeks kekayaan dengan tingkat fertilitas disebabkan karena sudah tercakupnya program keluarga berencana di seluruh kalangan sehingga baik kalangan dengan indeks kekayaan rendah maupun tinggi sama-sama memiliki partisipasi dalam keikutsertaan KB. Meningkatnya kesadaran WUS berstatus ekonomi rendah mengenai perlunya mengontrol jumlah kelahiran anak merupakan hasil dari upaya pemerintah yang optimal dalam melakukan sosialisasi, pelayanan dan pemberian informasi kepada seluruh WUS (Sunaryanto, 2012).

\section{KESIMPULAN DAN SARAN}

Umur seks pertama, umur kawin pertama, umur pertama melahirkan, lama penggunaan kontrasepsi dan jumlah anak ideal berhubungan signifikan dengan tingkat fertilitas di Provinsi Kalimantan Timur. Regresi ridge menjadi model prediksi terbaik dengan nilai standar error yang lebih kecil dibandingkan nilai standar error MKT sehingga pemodelan yang dihasilkan regresi ridge lebih baik dalam memprediksi jumlah anak lahir hidup (fertilitas) di Provinsi Kalimantan Timur tahun 2017.

Adapun saran dari penelitian ini yaitu perlunya program penyuluhan dan sosialisasi bagi WUS untuk meningkatkan pengetahuan mengenai kesehatan reproduksi Untuk penelitian selanjutnya dapat menggunakan metode lain untuk mengatasi masalah multikolinieritas seperti metode komponen utama (Principal Component Analysis) serta dapat dibandingkan dengan metode regresi ridge untuk memperoleh hasil terbaik.

\section{REFERENSI}

Adi, E. S. (2013) Faktor yang Mempengaruhi Fertilitas di Desa Kandangtepus Kecamatan Senduro Kabupaten Lumajang. Universitas Jember. Tersedia pada: https://repository.unej.ac.id/bitstream/handle/1 23456789/5660/Endru Setia Adi 080810101052.pdf?sequence $=1$.

Arsyad, S. S. dan Nurhayati, S. (2016). "Determinan Fertilitas Di Indonesia ( Determinant of Fertility in Indonesia )," Kependudukan Indonesia, 11(1), hal. 1-14. Tersedia pada: http://ejurnal.kependudukan.lipi.go.id/index.ph $\mathrm{p} / \mathrm{jki} /$ article/view/65/96.

Basuki, A. T. (2016). Pengantar Ekonometrika (Dilengkapi Penggunaan Eviews). Yogyakarta: Danisa Media.

Cenia, A. V. (2017). "Persepsi Usia Menikah Ideal dengan Jumlah Anak yang Diinginkan Pada Remaja Kelas XI di SMA N 1 Depok Sleman Yogyakarta," Universitas Asyiyah Yogyakarta.

Chatterjee, S. dan Hadi, A. S. (2006) Regression Analysis by Example. 4 ed. USA: John Wiley \& Sons.

Cicih, L. H. M. (2019) Info demografi. Jakarta: LDFEB Universitas Indonesia.

Hanum, N. dan Andiny, P. (2018) "Pengaruh Tingkat Pendidikan, Usia Perkawinan Pertama dan Kematian Bayi terhadap Fertilitas di Kabupaten Aceh Timur," Jurnal Samudra Ekonomi dan Bisnis, 9(2), hal. 160-170. doi: 10.33059/jseb.v9i2.764.

Kurniawan, R. dan Yuniarto, B. (2016) ANALISIS REGRESI: Dasar dan Penerapannya dengan R. Jakarta: PT. Kharisma Putra Utama.

Montgomery, D. C., Peck, E. A. dan Geoffrey, V. G. (2012) Introduction to linear regression analysis. 5 ed. Canada: John Wiley \& Sons.

Nasution, S. L. (2012) 'Pengaruh Pengetahuan Tentang Kesehatan Reproduksi Remaja Terhadap Perilaku Seksual Pranikah Remaja Di Indonesia,” Journal of Widyariset, 15(1), hal. 75-84. http://widyariset.pusbindiklat.lipi.go.id/index.php /widyariset/article/viewFile/27/22. 
Oktriyanto, Puspitawati, H. dan Muflikhati, I. (2015) "Nilai Anak dan Jumlah Anak yang Diinginkan Pasangan Usia Subur di Wilayah Perdesaan dan Perkotaan," Jurnal Ilmu Keluarga dan Konsumen, 8(1), hal. 1-9. doi: 10.24156/jikk.2015.8.1.1.

Pontoh, A. H. (2018) "Tingkat Karakteristik (Umur, Paritas, Pendidikan) Ibu Hamil Tentang Kejadian Kehamilan Resiko Tinggi," Griya Husada, hal. 52-59.

Pratama, S. A. N., Trisnaningsih dan Zulkarnain (2017) "Hubungan Lama Pendidikan Nilai Anak dan Usia Kawin Pertama dengan Jumlah Anak," Universitas Lampung. doi: 10.1017/CBO9781107415324.004.

Raharja, M. B. (2014) "Fertilitas Remaja di Indonesia," Kesmas: National Public Health Journal, $9(1), \quad$ hal. $6 . \quad$ doi: 10.21109/kesmas.v9i1.449.

Rahman, K. dan Muslimin, I. (2020) "Umur Pertama Kali Melakukan Hubungan Seks Pada Pasangan Menikah Di Provinsi Sulawesi Barat," Jurnal Ilmiah STIKES Kendal, 10(1), hal. $63-70$.

Saraswati, S., Trisnaningsih dan Zulkarnain (2018) "Hubungan Lama Pendidikan Usia Kawin Pertama Dan Lama Menggunakan Alat Kontrasepsi Dengan Jumlah Anak," Jurnal Penelitian Geografi, 6(1).

Sari, N. (2017) "Determinan Fertilitas Melalui Pendekatan Total Fertility Rate (Tfr) Di Indonesia: Analisis Data Survei Demografi Kesehatan Indonesia (Sdki) Tahun 2007," Dunia Kesmas, $6 . \quad$ doi: 10.1017/CBO9781107415324.004.

Saskara, I. ayu gde dyastari dan Marhaeni, A. agung istri ngurah (2015) "Pengaruh Faktor Sosial, Ekonomi dan Demografi Terhadap Penggunaan Kontrasepsi di Denpasar," Jurnal ekonomi kuantitatif terapan, 8(2), hal. 155161.
Schneider, A., Hommel, G. dan Blettner, M. (2010) "Linear regression analysis," Deutsches Arzteblatt, 107(44), hal. 776-782. doi: 10.3238/arztebl.2010.0776.

SDKI (2017) Survey Demografi dan Kesehatan Indonesia, Survei Demografi dan Kesehatan Indonesia. Jakarta: BKKBN, BPS, Kementerian Kesehatan, dan ICF International. doi: 0910383107 [pii] \r10.1073/pnas.0910383107.

Sinaga, L., Hardiani dan Prihanto, P. H. (2017) "Faktor-faktor yang mempengaruhi tingkat fertilitas di perdesaan (Studi pada Desa Pelayangan Kecamatan Muara Tembesi Kabupaten Batanghari)," Jurnal Paradigma Ekonomika, 12(1).Tersedia pada: https://online-

journal.unja.ac.id/index.php/paradigma/article/ view/3933.

Sunaryanto, H. (2012) “Analisis Fertilitas Penduduk : Provinsi Bengkulu ( the Analysis of Population Fertility: Bengkulu Province )," Analisis Fertilitas Penduduk: Provinsi Bengkulu, VII(1), hal. 19-38. Tersedia pada: http://ejurnal.kependudukan.lipi.go.id/index.ph $\mathrm{p} / \mathrm{jki} /$ article/download/81/73.

Winta, M. V. I. dan Syafitri, A. K. (2019) “Coping Stress Pada Ibu Yang Mengalami Kematian Anak," PHILANTHROPY: Journal of Psychology, 3(1), hal. 14. doi: 10.26623/philanthropy.v3i1.1513.

Yuniarti, S. dan Setiowati, T. (2015) "Analisis Faktor yang Berhubungan dengan Tingkat Fertilitas pada Ibu Pasangan Usia Subur ( PUS ) di Wilayah Kerja PUSKESMAS Melong Asih Kota Cimahi," Politeknik Negeri Bandung.

Zulkifli, Amri dan Munawar, E. (2020) "Analisis fertilitas di provinsi aceh," Perspektif Ekonomi Darussalam, 6, hal. 54-71. 